\title{
PENGARUH PEMBERIAN NATRIUM ALGINAT TERHADAP PENURUNAN KADAR GLUKOSA DARAH TIKUS
}

\author{
Thamrin Wikanta"), Khaeroni"), dan Lestari Rahayu")
}

\begin{abstract}
ABSTRAK
Makalah ini melaporkan tentang pengaruh pemberian natrium alginat terhadap penurunan kadar glukosa darah tikus yang telah mengalami perusakan sel beta pankreas menggunakan aloksan. Dibuat 5 kelompok perlakuan hewan coba (tikus), masing-masing terdiri dari 5 ekor. Hewan coba dibuat mengalami kondisi hiperglikemia dengan injeksi aloksan dosis $125 \mathrm{mg} / \mathrm{kg}$ bobot badan dan kondisi hiperglikemia dicapai pada hari ke 7. Tiap kelompok masing-masing diberikan secara oral akuades, natrium alginat $0,25,0,5,1,0 \mathrm{~g} / \mathrm{kg}$ bobot badan, dan injeksi secara intravena insulin dosis $3,78 \mathrm{Ul} / \mathrm{kg}$ bobot badan. Kadar glukosa darah diamati pada saat normal (sebelum diberikan injeksi aloksan), sebelum pemberian sediaan uji dan 2,5 jam setelah pemberian sediaan uji. Pemberian sediaan uji dilakukan setiap hari selama 15 hari dan kadar glukosa darah diukur secara periodik dengan interval waktu 5 hari menggunakan glukometer. Hasil penelitian menunjukkan bahwa semua sediaan uji menimbulkan efek menurunkan kadar glukosa darah. Penurunan kadar glukosa darah akibat pemberian natrium alginat dosis $1 \mathrm{~g} / \mathrm{kg}$ bobot badan lebih besar dari pada dosis $0,5 \mathrm{~g} / \mathrm{kg}$ bobot badan dan jauh lebih besar dari pada dosis $0,25 \mathrm{~g} / \mathrm{kg}$ bobot badan. Penurunan kadar glukosa darah akibat pemberian injeksi insulin lebih besar dari pada akibat pemberian setiap dosis sediaan uji natrium alginat. Berdasarkan analisis histologi dan kadar glukosa darah sebelum perlakuan, pemberian sediaan uji natrium alginat menunjukkan indikasi membantu mempercepat proses perbaikan sel beta pankreas yang rusak akibat pemberian aloksan, dan laju proses perbaikan sel beta pankreas lebih cepat setelah pemberian sediaan uji natrium alginat dari pada setelah pemberian injeksi insulin.
\end{abstract}

\section{ABSTRACT: The Effect of Sodium Alginate Feeding on the Reduction of Rats Blood Glucose Level. By: Thamrin Wikanta, Khaeroni, and Lestari Rahayu}

This paper reports on the effect of sodium alginate feeding on the reduction of blood glucose level in rats that have the pancreatic beta cell defected by aloxan. There were 5 groups of rats, each group contained 5 animals. The animals were made hyperglycemic condition by aloxan injection with the dose of $125 \mathrm{mg} / \mathrm{kg}$ body weight and the hyperglycemic condition were reached at the seventh days. Each group, respectively, was given orally distillated water, sodium alginate with the dose of $0.25,0.5,1,0 \mathrm{~g} / \mathrm{kg}$ body weight, and insulin injected through intravena with the dose of $3,78 \mathrm{IU} / \mathrm{kg}$ body weight. The rat blood glucose levels were measured at the normal condition (before aloxan injection), before sodium alginate treatments and 2.5 hours after sodium alginate treatments. Sodium alginate treatments were conducted every day for 15 days, and blood glucose levels were measured priodically with 5 days interval using glucometer. The result showed that all sodium alginate treatments were able to reduce blood glucose level. Reduction of blood glucose level after sodium alginate treatment with the dose of $1,0 \mathrm{~g} / \mathrm{kg}$ body weight was higher than the dose of $0.5 \mathrm{~g} / \mathrm{kg}$ body weight and much higher than the dose of $0.25 \mathrm{~g} / \mathrm{kg}$ body weight. Reduction of blood glucose level after insulin injection was higher than after sodium alginate treatments. Based on the hystological analysis and blood glucose level before treatments, sodium alginate treatments showed an indication to support the acceleration of recovery process of pancreatic beta cell defected by aloxan treatment. The rates of pancreatic beta cell recovery process were faster after sodium alginate treatments than insulin injection.

KEYWORDS: sodium alginate, rats blood glucose level

\footnotetext{
-) Peneliti pada Pusat Riset Pengolahan Produk dan Sosial Ekonomi Kelautan dan Perikanan

-) Fakultas Farmasi - Universitas Pancasila, Jakarta
} 


\section{PENDAHULUAN}

Alginat merupakan zat fikokoloid hasil ekstraksi dari rumput laut coklat jenis Laminaria sp, Macrocystis sp, Ascophyllum $\mathrm{sp}$, Sargassum sp, Turbinaria sp, Dyctiota sp, dil. Jenis rumput laut coklat yang tumbuh melimpah dan tersebar luas di seluruh perairan Indonesia diantaranya adalah Sargassum sp. dan Turbinaria sp. (Atmadja, 1988; Wikanta, 1996; Wikanta, 1998). Alginat merupakan senyawa serat yang tersusun dari gugusan asam manuronat dan asam guluronat yang mempunyai kemampuan menyerap air sangat besar dan kuat dengan membentuk gel atau larutan kental (Glickșman, 1983'; Suzuki et al., 1994).

Alginat banyak digunakan dalam berbagai bidang industri, seperti: industri tekstil, kertas, makanan, minuman dan farmasi. Dalam industri farmasi alginat digunakan sebagai zat pensuspensi, penstabil emulsi, pengikat dan penghancur tablet (Anggadiredja, 1992), juga digunakan bersama antasida atau antagonis reseptor $\mathrm{H} 2$ seperti simetidin karena natrium alginat dapat bereaksi dengan asam lambung membentuk gel dan menaikan $\mathrm{pH}$ cairan lambung (Reynolds, 1993; Wade and Weller, 1994).

Diabetes melitus yang dikenal sebagai penyakit kencing manis adalah jenis penyakit yang ditandai dengan kadar glukosa darah yang melebihi normal (hiperglikemia) akibat tubuh kekurangan insulin, baik secara absolut maupun relatif. Komplikasi yang mungkin timbul akibat penyakit diabetes melitus di antaranya adalah gangguan pembuluh darah besar (makroangiopati) yang dapat menyebabkan kerusakan pada jantung, otak, dan kaki, serta gangguan pembuluh darah kecil (mikroangiopati) yang dapat menyebabkan kerusakan pada ginjal, mata, dan saraf (Ganiswara, 1995). Menurut Tjokroprawiro (1999) penderita diabetes melitus ditandai dengan kadar glukosa darah puasa $>120 \mathrm{mg} / \mathrm{dl}$ atau kadar glukosa darah sewaktu > $200 \mathrm{mg} / \mathrm{dl}$. Menurut Ganong (1992), penderita diabetes akan memiliki kadar glukosa darah yang tinggi berdasarkan hasil pemeriksaan laboratorium disertai dengan timbulnya gejala khas diabetes, yaitu banyak minum (polidipsia) karena rasa haus terus, banyak kencing (poliuria), dan banyak makan (polifagia). Penderita diabetes lazimnya mengalami penurunan bobot badan yang sangat cepat.
Terdapat 2 jenis utama penyakit diabetes melitus (Katzung, 1989), yaitu; tipe I, diabetes melitus tergantung insulin (Insulin Dependent Diabetes Mellitus, IDDM), dan tipe II, diabetes melitus tak tergantung insulin (Non Insulin Dependent Diabetes Mellitus, NIDDM). NIDDM lazim terjadi pada manusia usia lanjut, sedangkan IDDM dapat terjadi pada manusia usia muda karena faktor bawaan.

Sifat alginat yang dapat membentuk gel atau larutan kental di dalam saluran cerna diharapkan dapat menahan laju absorpsi berbagai nutrisi (termasuk glukosa) dari saluran cerna melalui mukosa usus ke dalam pembuluh darah sehingga dapat menahan laju peningkatan kadar glukosa di dalam darah (Glicksman, 1983 ${ }^{\mathrm{a}}$ ). Untuk mengetahui efektifitas senyawa alginat dalam mereduksi kadar glukosa darah maka penggunaan natrium alginat perlu dibandingkan terhadap penggunaan insulin yang merupakan obat antidiabetes melitus standar yang lazim digunakan bagi penderita diabetes melitus tergantung insulin (IDDM).

\section{BAHAN DAN METODE}

\section{Bahan}

\section{Hewan Coba}

Hewan coba yang digunakan adalah tikus putih (Rattus norvegicus), jenis jantan berumur 3-3,5 bulan, bobot badan 200-250 gram sebanyak 25 ekor, didapat dari Pusat Penelitian Obat dan Makanan (PPOM), Jakarta. Sebelum digunakan dalam percobaan, semua tikus dipelihara terlebih dahulu selama sekitar satu minggu untuk penyesuaian lingkungan, mengontrol kesehatan dan bobot badannya, serta menyeragamkan makanannya. Selama penelitian berlangsung tikus diberi makanan pelet dengan komposisi nutrisi standar dan minum air matang (KKI Phytomedica, 1993).

\section{Senyawa alginat}

Senyawa alginat yang digunakan dalam penelitian ini adalah natrium alginat dengan viskositas $2000 \mathrm{cps}\left(2 \%, 25^{\circ} \mathrm{C}\right)$ yang diperoleh dari Pusat Riset Pengolahan Produk dan Sosial Ekonomi Kelautan dan Perikanan, Jakarta, merupakan hasil ekstraksi dari rumput laut coklat jenis Sargassum filipendula yang dipanen dari alam di perairan Binuangeun-Propinsi Banten. 


\section{Metode}

\section{Pembuatan tikus hiperglikemik}

Metoda yang digunakan adalah uji diabetes aloksan sebagai suatu model diabetes melitus tergantung insulin (IDDM). Hewan coba dirusak pankreasnya dengan pemberian suntikan aloksan dosis $125 \mathrm{mg} / \mathrm{kg}$ bobot badan. Penggunaan dosis $125 \mathrm{mg} / \mathrm{kg}$ bobot badan dianggap paling aman untuk tikus setelah melalui orientasi uji dosis.

Sebelum diberikan perlakuan, tikus diberi suntikan aloksan. Pada hari ke-7 dilakukan pengambilan darah untuk memastikan bahwa tikus telah mengalami hiperglikemik, kemudian tikus dipuasakan selama kurang lebih 16 jam. Selanjutnya pengambilan darah dilakukan saat sebelum dan sesudah pemberian sediaan perlakuan, pada hari ke: $0,5,10$, dan 15. Kadar glukosa darah tikus diukur dengan menggunakan alat glukometer life scan (Johnson \& Johnson, 1995).

\section{Perhitungan dosis insulin (Laurence and Bacharah, 1964)}

Dosis untuk manusia dewasa $50 \mathrm{~kg}$ bobot badan $=30$ unit/hari

Dosis untuk manusia dewasa $70 \mathrm{~kg}$ bobot badan $=70 / 50 \times 30$ unit/hari $=42$ unit/hari .

Dosis untuk tikus $200 \mathrm{~g}$ harus dikalikan faktor konversinya, yaitu: 0,018.

Maka dosis untuk tikus $=42 \times 0,018$ unit $=$ $0,756 \mathrm{unit} / \mathrm{hari} / 200 \mathrm{~g}$ bobot badan $=3,78$ unit /hari/kg bobot badan.

\section{Cara kerja}

- Semua tikus dipelihara selama 1 minggu

- Masing-masing tikus yang akan digunakan dalam penelitian ditimbang, cuplikan darah diambil melalui vena ekor tikus.

- Tikus didiabeteskan dengan suntikan aloksan dosis $125 \mathrm{mg} / \mathrm{kg}$ bobot badan secara intravena.

- Semua tikus yang telah didiabeteskan dipelihara selama 1 minggu agar mengalami kondisi hiperglikemik.

- Semua tikus dipuasakan selama kurang lebih 16 jam.

- Pengambilan darah awal dilakukan melalui vena ekor dari masing-masing tikus sebelum diberikan sediaan uji dan kadar glukosa darah awalnya diukur.

- Tikus dibagi dalam 5 kelompok, tiap kelompok terdiri dari 5 ekor, masing. masing kelompok diberi perlakuan sebagai berikut:

a. kelompok I, kontrol negatif diberi air suling ( $5 \mathrm{ml} / \mathrm{kg}$ bobot badan).

b. kelompok II, diberi natrium alginat 0,25 $\mathrm{g} / \mathrm{kg}$ bobot badan $(5 \mathrm{ml} / \mathrm{kg}$ bobot badan)

c. kelompok III, diberi natrium alginat 0,5 $\mathrm{g} / \mathrm{kg}$ bobot badan $(5 \mathrm{ml} / \mathrm{kg}$ bobot badan)

d. kelompok IV, diberi natrium alginat 1,0 $\mathrm{g} / \mathrm{kg}$ bobot badan $(5 \mathrm{ml} / \mathrm{kg}$ bobot badan).

e. kelompok $V$, kontrol positif diberi injeksi insulin dosis 3,78 unit/kg bobot badan.

Semua sediaan sesuai dosis tersebut diberikan secara oral setiap hari selama 15 hari, sedangkan obat pembanding (kontrol positif) diberikan secara parenteral.

- Sebelum dan 2,5 jam setelah pemberian sediaan uji, darah tikus dicuplik pada hari ke: 0, 5, 10 dan 15, lalu kadar glukosa darahnya diukur dengan alat glukometer

- Setelah selesai pemberian sediaan uji, semua tikus dimasukkan ke dalam kandangnya masing-masing dan diberi makan dan minum.

Setiap kali pengambilan darah, tikus harus dipuasakan terlebih dahulu kurang lebih 16 jam

\section{HASIL. DAN PEMBAHASAN}

\section{Pengukuran Kadar Glukosa Darah}

Pengamatan kadar glukosa darah dilakukan setiap 5 hari dimulai dari keadaan awal saat tikus belum mendapat perlakuan (kondisi normal), dilanjutkan setelah tikus mengalami kondisi hiperglikemia pada hari ke $0,5,10,15$ sebelum dan setelah pemberian injeksi aloksan. Data hasil pengamatan berdasarkan kelompok perlakuan dapat dilihat pada Tabel 1.

Berdasarkan kelompok perlakuan kemudian dibuat grafik yang menunjukkan hubungan antara waktu pengamatan dengan kadar glukosa darah seperti pada Gambar 16. Setelah itu diperoleh luas daerah dibawah kurva (LDDK) sebelum dan sesudah perlakuan. Uji homogenitas dari Barlett menunjukkan kadar glukosa darah bervariasi homogen sedangkan uji kenormalan menunjukkan kadar glukosa darah berdistribusi tidak normal, maka selanjutnya 
Tabel 1. Nilai rata-rata kadar glukosa darah (mg/dl) tikus sesuai perlakuan.

Table 1. Mean of rats blood glucose level (mg/di) according to treatments.

\begin{tabular}{|c|c|c|c|c|c|c|c|c|c|}
\hline \multirow{3}{*}{$\begin{array}{c}\text { Dosis } \\
\text { sediaan uji } \\
\text { Dosage of } \\
\text { treatment }\end{array}$} & \multirow{3}{*}{$\begin{array}{c}\text { Kadar } \\
\text { glukosa } \\
\text { darah awal/ } \\
\text { Initial } \\
\text { blood } \\
\text { glucose } \\
\text { level } \\
\text { (mg/dl) }\end{array}$} & \multicolumn{8}{|c|}{$\begin{array}{l}\text { Waktu Pengamatan (hari) sesuai perlakuan } \\
\text { Time of measurement (day) according to treatments }\end{array}$} \\
\hline & & \multicolumn{2}{|c|}{0} & \multicolumn{2}{|c|}{5} & \multicolumn{2}{|c|}{10} & \multicolumn{2}{|c|}{15} \\
\hline & & $\begin{array}{l}\text { Sebe- } \\
\text { lum/ } \\
\text { Before }\end{array}$ & $\begin{array}{l}\text { Sesu- } \\
\text { dah/ } \\
\text { After }\end{array}$ & $\begin{array}{l}\text { Sebe- } \\
\text { lum/ } \\
\text { Before }\end{array}$ & $\begin{array}{l}\text { Sesu- } \\
\text { dah/ } \\
\text { After }\end{array}$ & $\begin{array}{l}\text { Sebe- } \\
\text { lum/ } \\
\text { Before }\end{array}$ & $\begin{array}{l}\text { Sesu- } \\
\text { dah/ } \\
\text { After }\end{array}$ & $\begin{array}{l}\text { Sebe- } \\
\text { lum/ } \\
\text { Before }\end{array}$ & $\begin{array}{l}\text { Sesu- } \\
\text { dah/ } \\
\text { After }\end{array}$ \\
\hline Akuades & & & & & & & & & \\
\hline $\begin{array}{l}\text { Distillated } \\
\text { water } \\
\text { Na-alginat }\end{array}$ & 94,0 & 204,2 & 201,0 & 190,4 & 187,2 & 180,2 & 177,2 & 167,6 & 165,0 \\
\hline $\begin{array}{l}\text { Na-alginate } \\
0,25 \mathrm{~g} / \mathrm{kg} \mathrm{BB} \\
\mathrm{Na} \text {-alginat }\end{array}$ & 89,6 & 200,8 & 178,0 & 151,6 & 132,6 & 121,2 & 103,4 & 90,8 & 82,4 \\
\hline $\begin{array}{l}\text { Na-alginate } \\
0,5 \mathrm{~g} / \mathrm{kg} \mathrm{BB} \\
\mathrm{Na} \text {-alginat }\end{array}$ & 90,4 & 203,0 & 173,4 & 145,0 & 117,6 & 114,6 & 91,2 & 91,0 & 79,8 \\
\hline $\begin{array}{l}\text { Na-alginate } \\
1,0 \mathrm{~g} / \mathrm{kg} \mathrm{BB}\end{array}$ & 88,8 & 208,0 & 173,4 & 142,0 & 111,0 & 110,2 & 84,6 & 88,4 & 75,2 \\
\hline $\begin{array}{l}\text { Insulin//nsulin } \\
3,78 \mathrm{UI} / \mathrm{kg} \text { BB }\end{array}$ & 89,2 & 214,0 & 95,2 & 187,6 & 81,6 & 173,2 & 70,8 & 155,2 & 62,5 \\
\hline
\end{tabular}

Catatan/Note: Ulangan/replication $(n)=5 ; B B=$ bobot badan/body weight

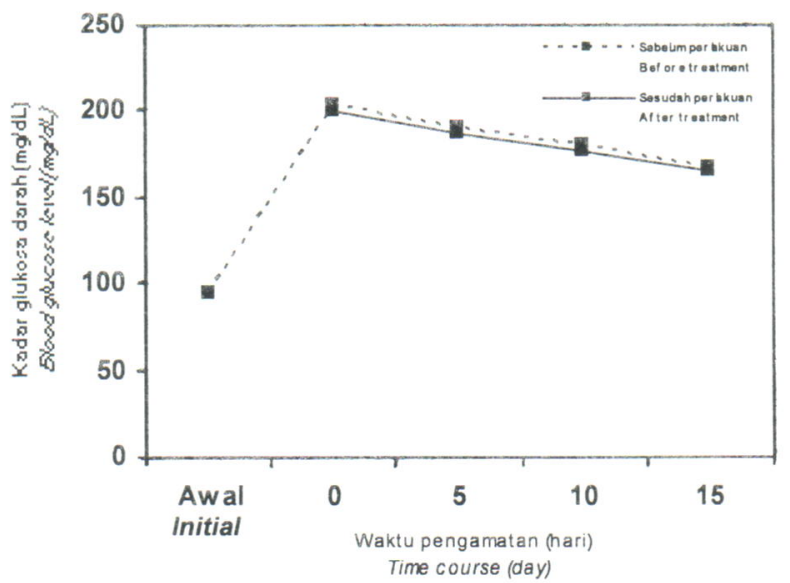

Gambar 1. Penurunan kadar glukosa darah tikus diabetik (mg/dL) sebelum dan sesudah perlakuan akuades dosis $5 \mathrm{ml} / \mathrm{kg} \mathrm{BB}$

Figure 1. Diabetic rat blood glucose level reduction ( $\mathrm{mg} / \mathrm{dL}$ ) before and after distilated water treatment with the dose of $5 \mathrm{ml} / \mathrm{kg} \mathrm{BW}$

dilakukan uji statistik non parametrik dan uji berganda Friedman terhadap data LDDK sebelum dan sesudah perlakuan, untuk mengetahui adanya perbedaan bermakna antar kelompok perlakuan. Hasil uji berganda Friedman menunjukkan bahwa ada perbedaan sangat nyata pada semua perlakuan yang diberikan dibandingkan dengan kontrol negatif, berarti semua perlakuan dapat menurunkan kadar glukosa darah tikus yang dirusak pankreasnya. Hasil uji berganda Friedman pada setiap kelompok perlakuan antara sebelum dan sesudah perlakuan menunjukkan terdapat perbedaan bermakna. Hasil uji-t dari masing-masing perlakuan terhadap data kadar glukosa darah sebelum perlakuan (kondisi normal) dan sesudah perlakuan selama 15 hari menunjukkan bahwa nilai T-hitung > nilai $\mathrm{T}$ tabel berarti semua pemberian sediaan menghasilkan kadar glukosa yang berbeda sangat nyata dengan kadar glukosa normal seperti dapat dilihat pada Tabel 2.

Hasil analisis statistik uji berganda Friedman menunjukkan bahwa: 
Tabel 2. Hasil analisis statistik uji-t dari kadar glukosa darah tikus sebelum (kondisi normal) dan sesudah perlakuan pemberian sediaan uji natrium alginat dan injeksi insulin selama 15 hari.

Table 2. The result of statistical analysis $t$-test of the rat blood glucose level before (the normal condition) and after sodium alginate and insulin treatment during 15 days.

\begin{tabular}{|c|c|c|}
\hline $\begin{array}{l}\text { Dosis perlakuan } \\
\text { Dosage of treatment }\end{array}$ & $\begin{array}{c}\text { Rata-rata kadar glukosa darah } \\
\text { tikus normal (sebelum perlakuan) } \\
\text { Mean of normal rat blood glucose } \\
\text { level (before treatment) }\end{array}$ & $\begin{array}{l}\text { Rata-rata kadar glukosa darah tikus } \\
\text { sesudah perlakuan selama } 15 \text { hari } \\
\text { Mean of rat blood glucose level } \\
\text { after treatment during } 15 \text { days }\end{array}$ \\
\hline $\begin{array}{l}\mathrm{Na} \text {-alginat } 0,25 \mathrm{~g} / \mathrm{kg} \mathrm{BB} \\
\mathrm{Na} \text {-alginate } 0.25 \mathrm{~g} / \mathrm{kg} \mathrm{BW}\end{array}$ & 89,6 & $82,4^{\star \star}$ \\
\hline $\begin{array}{l}\text { Na-alginat } 0,50 \mathrm{~g} / \mathrm{kg} \mathrm{BB} \\
\text { Na-alginate } 0.50 \mathrm{~g} / \mathrm{kg} \mathrm{BWW}\end{array}$ & 90,4 & $79,8^{* *}$ \\
\hline $\begin{array}{l}\mathrm{Na} \text {-alginat } 1,0 \mathrm{~g} / \mathrm{kg} \mathrm{BB} \\
\mathrm{Na} \text {-alginate } 1.0 \mathrm{~g} / \mathrm{kg} \mathrm{BW}\end{array}$ & 88,8 & $75,2^{\star \star \star}$ \\
\hline $\begin{array}{l}\text { Insulin 3,78 UI/kg BB } \\
\text { Insulin } 3.78 \mathrm{U} / \mathrm{kg} \mathrm{BW}\end{array}$ & 89,2 & $62,5^{\star *}$ \\
\hline
\end{tabular}

Catatan / Note:

UI = Unit internasional//nternational Unit;

$\mathrm{BB}=$ bobot badan/body weight.

** = Sangat berbeda nyata/Highly significant different;

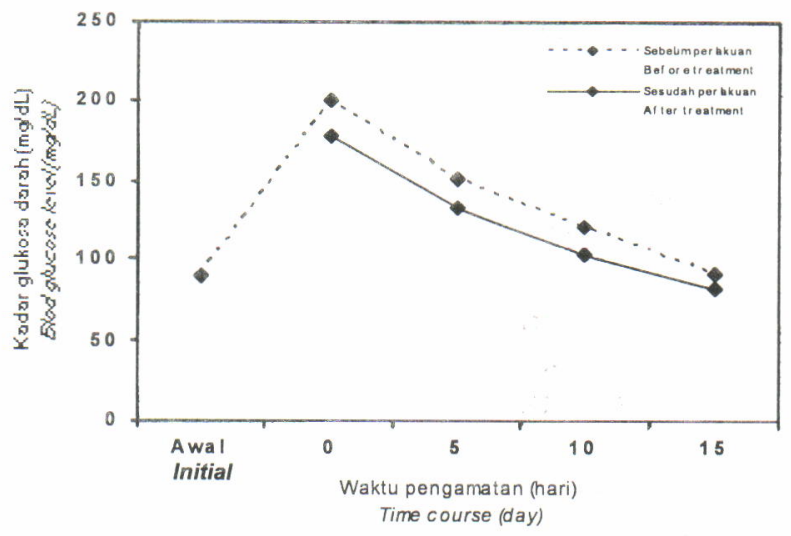

Gambar 2. Penurunan kadar glukosa darah tikus diabetik (mg/dL) sebelum dan sesudah perlakuan $\mathrm{Na}$-alginat dosis $0.25 \mathrm{~g} / \mathrm{kg} \mathrm{BB}$

Figure 2. Diabetic rat blood glucose level reduction $(\mathrm{mg} / \mathrm{dL})$ before and after Na-alginate treatment with the dose of $0.25 \mathrm{~g} / \mathrm{kg} \mathrm{BW}$

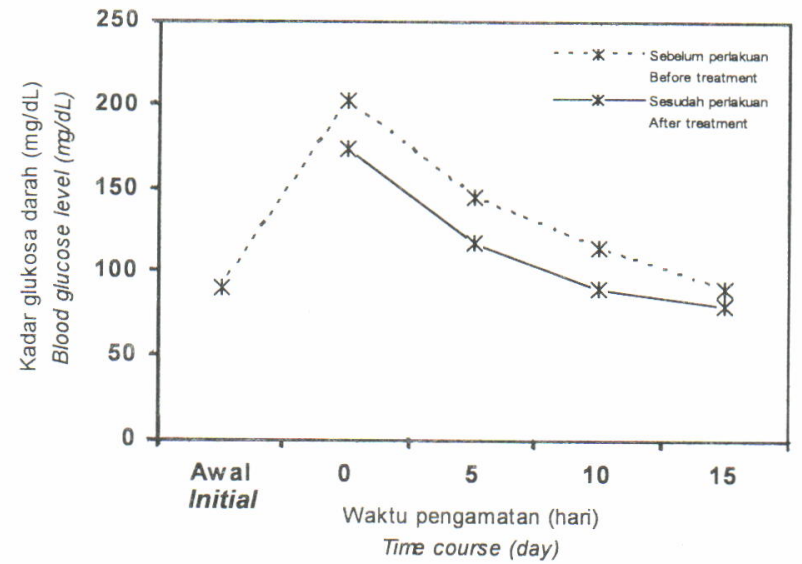

Gambar 3. Penurunan kadar glukosa darah tikus diabetik ( $\mathrm{mg} / \mathrm{dL}$ ) sebelum dan sesudah perlakuan $\mathrm{Na}$-alginat dosis $0.50 \mathrm{~g} / \mathrm{kg} \mathrm{BB}$

Figure 3. Diabetic rat blood glucose level reduction $(\mathrm{mg} / \mathrm{dL})$ before and after Na-alginate treatment with the dose of $0.50 \mathrm{~g} / \mathrm{kg} \mathrm{BW}$ 


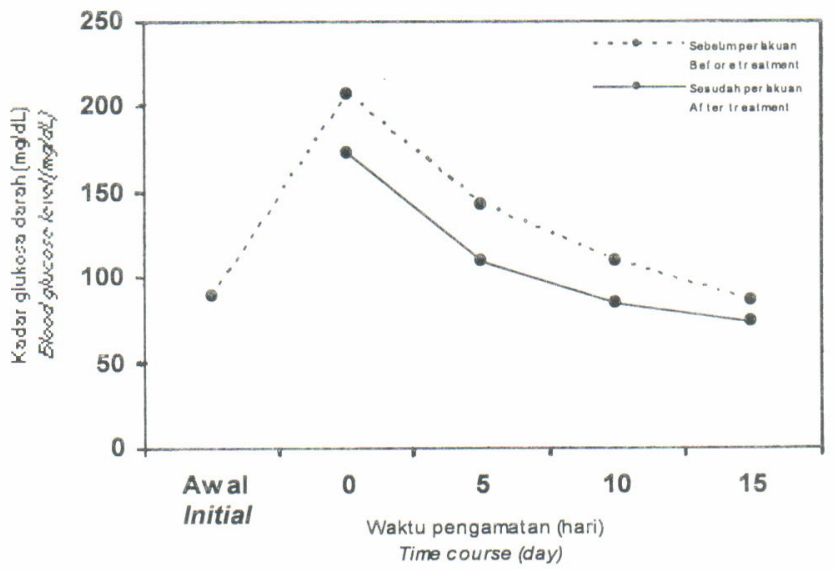

Gambar 4. Penurunan kadar glukosa darah tikus diabetik $(\mathrm{mg} / \mathrm{dL})$ sebelum dan sesudah perlakuan Na-alginat dosis $1.0 \mathrm{~g} / \mathrm{kg} \mathrm{BB}$

Figure 4. Diabetic rat blood glucose level reduction $(\mathrm{mg} / \mathrm{dL})$ before and after $\mathrm{Na}$-alginate treatment with the dose of $1.0 \mathrm{~g} / \mathrm{kg} \mathrm{BW}$

1. Semua pemberian sediaan natrium alginat dibandingkan kontrol negatif menunjukkan perbedaan sangat nyata, berarti bahwa semua sediaan yang diberikan dapat menurunkan kadar glukosa darah tikus yang dirusak pankreasnya. Masing-masing dosis sediaan natrium alginat menimbulkan efek menurunkan kadar glukosa darah tikus yang berbeda. Perbedaan dosis menimbulkan perbedaan kekentalan cairan saluran cerna, yang selanjutnya menimbulkan perbedaan kemampuan dan kekuatan pengikatan glukosa dan nutrien-nutrien oleh cairan saluran cerna, sehingga menimbulkan perbedaan laju absorpsi glukosa dan nutrien-nutrien tersebut dari saluran cerna ke dalam pembuluh darah. Pada akhirnya laju peningkatan kadar glukosa darah menjadi sangat terpengaruh.

2. Hasil dari setiap pengukuran kadar glukosa darah sebelum perlakuan pemberian sediaan uji natrium alginat dan insulin (Tabel 3) menunjukkan bahwa efek menurunkan kadar glukosa darah tikus yang diakibatkan oleh pemberian natrium alginat secara berurutan, dosis $1 \mathrm{~g} / \mathrm{kg}$ bobot badan $(28,05 \%)$ lebih besar dari pada dosis $0,5 \mathrm{~g} / \mathrm{kg}$ bobot badan $(26,94 \%)$ dan lebih besar dari pada dosis $0,25 \mathrm{~g} / \mathrm{kg}$ bobot badan $(24,78 \%)$ dan jauh lebih besar dari pada pemberian insulin dosis $3,78 \mathrm{UI} / \mathrm{kg}$ bobot badan $(1,99 \%)$.

3. Hasil dari setiap pengukuran kadar glukosa darah sesudah perlakuan pemberian sediaan uji natrium alginat dan insulin (Tabel 3) menunjukkan bahwa efek menurunkan kadar glukosa darah tikus yang diakibatkan oleh pemberian insulin dosis $3,78 \mathrm{UI} / \mathrm{kg}$ bobot badan $(57,77 \%)$ lebih besar dari pada natrium alginat dosis

Tabel 3. Persentase penurunan kadar glukosa darah tikus sebelum dan sesudah perlakuan.

Table 3. The precentage of rat blood glucose level reduction before and after treatment.

\begin{tabular}{lcc}
\hline \multicolumn{1}{c}{$\begin{array}{c}\text { Dosis Sediaan Uji } \\
\text { Dosage of treatment }\end{array}$} & $\begin{array}{c}\text { Penurunan kadar glukosa darah tikus (\%) } \\
\text { Reduction of rat blood glucose level (\%) }\end{array}$ \\
\hline $\begin{array}{l}\text { Sebelum perlakuan } \\
\text { Before treatment }\end{array}$ & $\begin{array}{c}\text { Sesudah perlakuan } \\
\text { After treatment }\end{array}$ \\
\hline $\begin{array}{l}\text { Na-alginat } 0,25 \mathrm{~g} / \mathrm{kg} \mathrm{BB} \\
\text { Na-alginate } 0.25 \mathrm{~g} / \mathrm{kg} \mathrm{BW}\end{array}$ & 24,78 & 33,18 \\
$\begin{array}{l}\text { Na-alginat } 0,50 \mathrm{~g} / \mathrm{kg} \mathrm{BB} \\
\text { Na-alginate } 0.50 \mathrm{~g} / \mathrm{kb} \mathrm{BW}\end{array}$ & 26,94 & 38,80 \\
$\begin{array}{l}\text { Na-alginat } 1,00 \mathrm{~g} / \mathrm{kg} \mathrm{BB} \\
\text { Na-alginate } 1.00 \mathrm{~g} / \mathrm{kg} \mathrm{BW} \\
\text { Injeksi insulin } 3,78 \mathrm{UI} / \mathrm{kg} \mathrm{BB} \\
\text { Insulin intravena } 3,78 \mathrm{IU} / \mathrm{kg} \mathrm{BW}\end{array}$ & 28,05 & 41,62 \\
\hline
\end{tabular}

Catatan/Note: UI = Unit internasional/International Unit; BB = bobot badan/body weight. 
$1 \mathrm{~g} / \mathrm{kg}$ bobot badan $(41,62 \%)$ lebih besar dari pada dosis $0,5 \mathrm{~g} / \mathrm{kg}$ bobot badan $(38,08 \%)$ lebih besar dari pada dosis 0,25 $\mathrm{g} / \mathrm{kg}$ bobot badan $(33,18 \%)$.

Pemberian sediaan natrium alginat dosis $0,25 \mathrm{~g} / \mathrm{kg}$ bobot badan, dosis $0,50 \mathrm{~g} / \mathrm{kg}$ bobot badan, dosis $1,0 \mathrm{~g} / \mathrm{kg}$ bobot badan dan injeksi insulin menimbulkan penurunan kadar glukosa darah yang nyata, hal ini terlihat dari adanya perbedaan yang bermakna antara kadar glukosa darah tikus pada keadaan normal dengan keadaan sesudah perlakuan pemberian sediaan uji selama 15 hari (Tabel 2).

Pemberian injeksi insulin selama 15 hari menunjukkan penurunan kadar glukosa darah

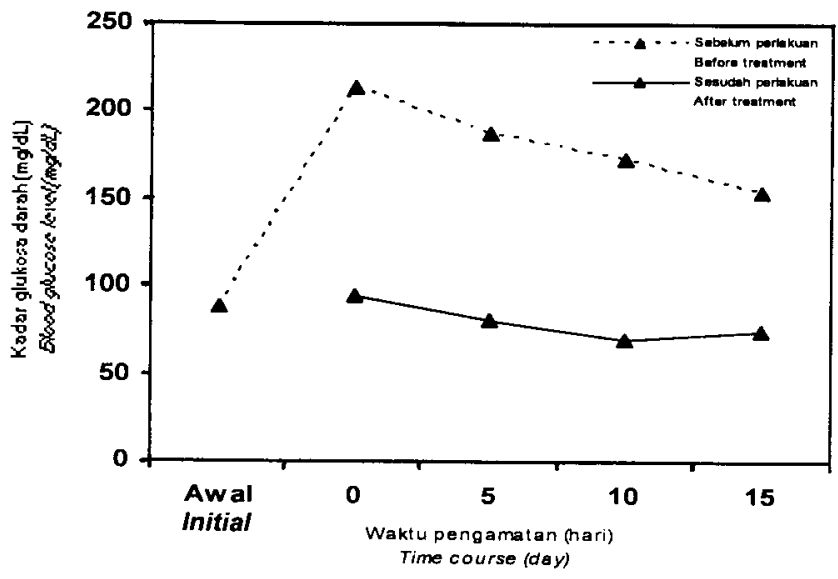

Gambar 5. Penurunan kadar glukosa darah tikus diabetik ( $\mathrm{mg} / \mathrm{dL}$ ) sebelum dan sesudah perlakuan injeksi Insulin dosis $3,78 \mathrm{Ul} / \mathrm{kg} \mathrm{BB}$

Figure 5. Diabetic rat blood glucose level reduction $(\mathrm{mg} / \mathrm{dL})$ before and after insulin injection with the dose of $3.78 \mathrm{U} 1 \mathrm{~kg} \mathrm{BW}$

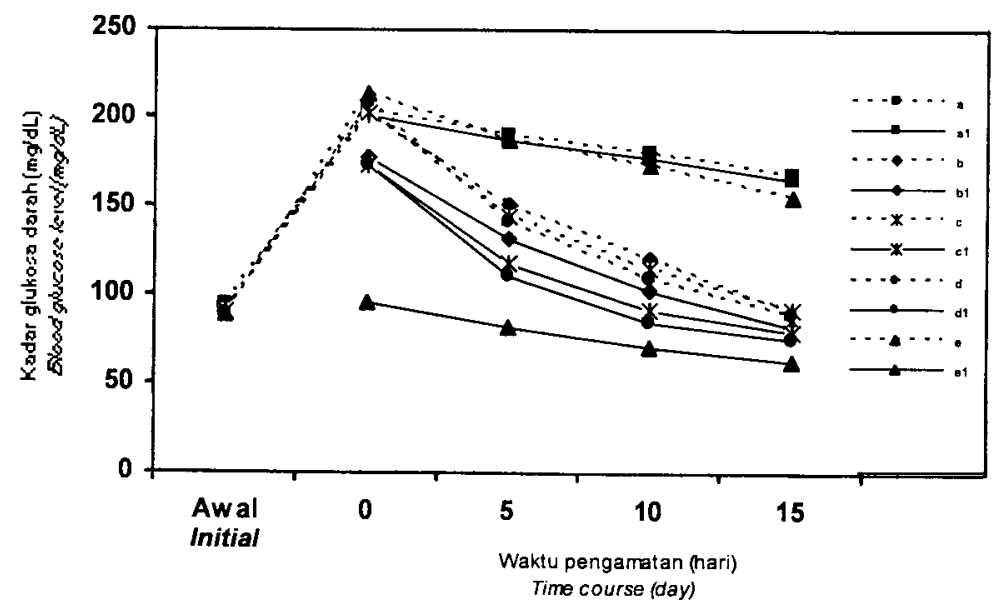

Gambar 6. Penurunan kadar glukosa darah tikus diabetik ( $\mathrm{mg} / \mathrm{dL}$ ) sebelum dan sesudah perlakuan: $a$ = sebelum perlakuan akuades; $a 1$ = sesudah perlakuan akuades; $b=$ sebelum perlakuan alginat $0,25 \mathrm{~g} / \mathrm{kg} B B ; b 1=$ sesudah perlakuan alginat $0,25 \mathrm{~g} / \mathrm{kg}$ $\mathrm{BB}$; $\mathrm{c}=$ sebelum perlakuan alginat $0,50 \mathrm{~g} / \mathrm{kg} \mathrm{BB}$; $\mathrm{c} 1=$ sesudah perlakuan alginat 0.5 $\mathrm{g} / \mathrm{kg} \mathrm{BB} ; d=$ sebelum perlakuan alginat $1.0 \mathrm{~g} / \mathrm{kg} B B, d 1=$ sesudah perlakuan alginat $1.0 \mathrm{~g} / \mathrm{kg} \mathrm{BB} ; \mathrm{e}=$ sebelum injeksi insulin $3.7 \mathrm{~g} \mathrm{Ul} / \mathrm{kg} \mathrm{BB}, \mathrm{e} 1$ = sesudah injeksi insulin $3.78 \mathrm{Ul} / \mathrm{kg} \mathrm{BB}$

Figure 6. Diabetic rat blood glucose level reduction $(\mathrm{mg} / \mathrm{dL})$ before and after treatment : $\mathrm{a}=$ before distilated water treatment, a1 $=$ after distilated water treatment, $b=$ before $\mathrm{Na}$ alginate $0.25 \mathrm{~g} / \mathrm{kg} \mathrm{BW}$ treatment, $b 1=$ after $\mathrm{Na}$-alginate $0.25 \mathrm{~g} / \mathrm{kg} \mathrm{BW}$ treatment, $c=$ before Na-alginate $0.50 \mathrm{~g} / \mathrm{kg} \mathrm{BW}$ treatment, c1 = after Na-alginate $0.50 \mathrm{~g} / \mathrm{kg}$ treatment, $d=$ before Na-alginate $1.0 \mathrm{~g} / \mathrm{kg} \mathrm{BW}$ treatment, $d 1=$ after Na-alginate 1.0 $\mathrm{g} / \mathrm{kg} \mathrm{BW}$ treatment, $e=$ before insulin injection $3.78 \mathrm{UI} / \mathrm{kg} \mathrm{BW}, \mathrm{e} 1=$ after insulin injection $3.78 \mathrm{Ul} / \mathrm{kg} \mathrm{BW}$. 
yang sangat berarti, tetapi setelah masa kerja insulin habis terlihat kadar glukosa darah kembali meningkat tinggi $(155,2 \mathrm{mg} / \mathrm{dl})$ seperti terlihat pada Tabel 1 dan Gambar 5. Pemberian natrium alginat dosis $0,25 \mathrm{~g} / \mathrm{kg}$ bobot badan, dosis $0,50 \mathrm{~g} / \mathrm{kg}$ bobot badan, dan dosis $1,0 \mathrm{~g} / \mathrm{kg}$ bobot badan mengindikasikan terjadinya perbaikan sel beta pankreas. Gambar 7a-d menunjukkan sel beta pankreas dalam keadaan normal berwarna coklat seluruhnya, sedangkan dalam kondisi diabetes (sesudah pemberian injeksi aloksan) hanya sebagian kecil sel beta pankreas yang berwarna coklat karena jaringan sel beta pankreas telah mengalami kerusakan oleh bahan kimia aloksan. Setelah perlakuan pemberian natrium alginat dosis $1 \mathrm{~g} / \mathrm{kg}$ bobot badan selama 10 hari dan 15 hari kondisi sel beta pankreas mengalami perbaikan yang terlihat dari makin luasnya wilayah yang berwarna coklat. Hal ini diduga karena natrium alginat dapat menurunkan asupan dan mengendalikan kadar glukosa darah tikus hingga kondisi normal, sehingga pada kondisi kadar glukosa darah yang normal tersebut proses metabolisme dapat berjalan secara normal dan proses perbaikan jaringan sel beta pankreas yang rusak akan berlangsung dengan lancar dan cepat. Adanya konsumsi makanan yang juga mengandung nutrien sebagai zat pembangun (protein, lemak dan vitamin) tentu turut menunjang percepatan proses perbaikan jaringan sel beta pankreas yang rusak.

Alginat merupakan senyawa serat yang bersifat dapat larut di dalam air tetapi tidak dapat dicerna oleh cairan di dalam saluran cerna. Senyawa ini memiliki kapasitas mengikat air sangat besar dan kuat karena bersifat polianionik (Chapman and Chapman, 1980). Makanan berserat memiliki dampak yang sangat besar terhadap alat pencernaan dan penyerapan unsur-unsur nutrisi di dalam saluran cerna. Khusus pada kondisi kadar glukosa yang berlebihan, alginat dapat menghambat proses penyerapan glukosa pada dinding usus halus karena di dalam saluran cerna natrium alginat akan membentuk gel atau cairan kental dan lembut (emulient) yang dapat menahan laju difusi glukosa dari saluran cerna ke dalam pembuluh darah sehingga dapat menahan laju peningkatan atau lonjakan kadar glukosa di dalam darah. Makanan yang berserat tersebut akan dapat mengatasi dan memperbaiki kondisi defisiensi insulin sehingga dianggap sebagai unsur untuk perbaikan.

Menurut Suzuki et al. (1994) tikus yang mengkonsumsi alginat memiliki kadar glukosa darah yang nyata lebih rendah (269-300 $\mathrm{mg} / \mathrm{dl}$ ) dari pada tikus kontrol yang tidak mengkonsumsi alginat $(380 \mathrm{mg} / \mathrm{dl})$, sedangkan hasil penelitian Wikanta et al. (2000) menunjukkan bahwa pada pemberian beban glukosa tinggi, kelinci yang mengkonsumsi alginat memiliki kadar glukosa darah nyata lebih rendah $(124 \mathrm{mg} / \mathrm{dl})$ dari pada kelinci kontrol yang tidak mengkonsumsi alginat $(149 \mathrm{mg} / \mathrm{dl})$.

Berdasarkan susunan natrium alginat, belum dapat diperkirakan seberapa besar rasio asam manuronat dan asam guluronat (M/G) yang dapat menimbulkan efek menurunkan kadar glukosa darah secara efektif. Menurut Suzuki et al. (1994), alginat yang kaya $M$ memiliki daya menurunkan kadar glukosa darah yang lebih besar dari pada alginat yang kaya $G$, tetapi tidak dijelaskan hubungannya dengan viskositas natrium alginat yang digunakan. Di samping proses penghambatan absorpsi nutrisi pada saluran cerna, mekanisme kerja lainnya dari alginat dalam menurunkan kadar glukosa darah dan dalam hubungannya dengan proses perbaikan jaringan sel beta pankreas belum dapat diketahui secara pasti, masih diperlukan penelitian lebih lanjut secara rinci dan mendalam berkaitan dengan histologi dari sel beta pankreas.

Menurut Hern et al. (1987), aktivitas proteinase (insulinase) menurun selama kondisi diabetes dan pulih ke keadaan normal menyertai perlakuan insulin. Hasil penelitian menunjukkan bahwa insulin berfungsi sebagai indikator proteinase pada jaringan liver dan jaringan adiposa. Berdasarkan hal tersebut maka tikus yang mendapatkan perlakuan insulin kadar glukosa darahnya menurun dengan tajam namun setelah daya kerja insulin habis karena didegradasi oleh insulinase maka kadar glukosa darahnya kembali meningkat tajam hingga hampir mendekati kondisi semula, sama seperti yang terjadi pada kondisi kontrol negatif yang mendapat perlakuan akuades. Pada tikus yang mendapatkan perlakuan natrium alginat, penurunan kadar glukosa darah tidak sebesar yang terjadi pada perlakuan insulin, tetapi setelah daya kerja natrium alginat habis insulin yang terdapat dalam jumlah sedikit di dalam jaringan masih dapat bekerja dengan baik secara berkelanjutan. Hal ini terjadi, 
diduga karena tidak adanya pemberian insulin dari luar yang dapat membantu memperlancar proses metabolisme dalam sel, yang mengubah glukosa menjadi energi, tetapi juga turut memicu meningkatkan aktivitas insulinase.

Tulsiani dan Touster (1981) mengemukakan bahwa penyakit diabetes berkaitan dengan berbagai abnormalitas metabolisme, juga dengan sistem kekebalan tubuh dan distribusi glikoprotein. Tikus yang diinduksi diabetes dengan bahan kimia streptozotocin, setelah 8 minggu mengalami penurunan bobot organ thymus hingga 80 $90 \%$ dan organ limpa hingga $50 \%$ dibandingkan kontrol, akibat proses degenerasi sel. Penurunan bobot organ disertai dengan penurunan kadar enzim hidrolase organ dan peningkatan enzim hidrolase plasma dan urin. Penurunan kadar enzim hidrolase disebabkan adanya kerusakan sel beta pankreas yang bersifat permanen (irreversible). Organ thymus dan limpa diduga menunjang terjadinya pening- katan enzim hidrolase plasma penderita diabetes. Perubahan kadar enzim hidrolase berkaitan dengan tingkat keparahan hiperglikemia. Pemulihan kondisi dapat dilakukan dengan perlakuan insulin. Hal ini terbukti dengan penghentian perlakuan insulin yang mengakibatkan terjadinya penurunan aktivitas enzim hidrolase dan bobot jaringan. Perlakuan insulin tersebut akan mempercepat normalisasi kadar glukosa darah sehingga pemulihan proses metabolisme di dalam tubuh akan berjalan lebih cepat dan proses perbaikan sel-sel atau jaringan yang mengalami kerusakan dapat berjalan dengan lancar. Upaya pemberian natrium alginat terbukti dapat mempercepat normalisasi kadar glukosa darah, ditunjang dengan hasil analisis histologi pankreas dengan metoda imunohistokimia yang menunjukkan indikasi terjadinya perbaikan sel beta pankreas yang telah rusak.

Dinyatakan oleh Dixit dan Kaung (1985) bahwa pada membran sel beta pankreas terdapat glukoreseptor, dan berbagai bukti
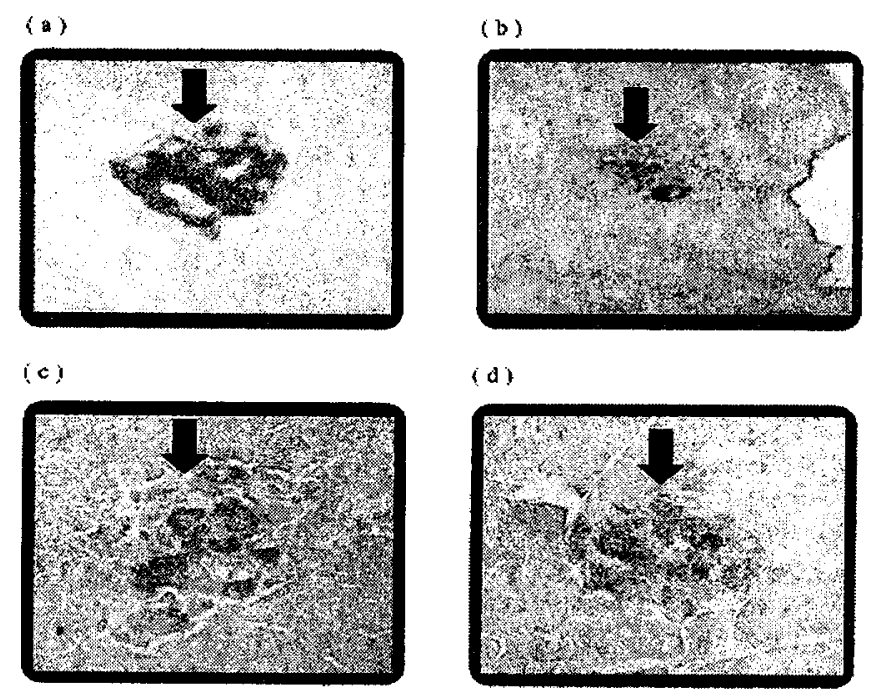

Gambar 7. Foto preparat sel beta pankreas tikus.

a. Preparat sel beta pankreas tikus normal (kontrol).

b. Preparat sel beta pankreas tikus yang rusak karena mendapat injeksi aloksan.

c. Preparat sel beta pankreas tikus yang rusak karena mendapat injeksi aloksan kemudian mengkonsumsi alginat dosis $1 \mathrm{~g} / \mathrm{kg}$ BB selama 10 hari.

d. Preparat sel beta pankreas tikus yang rusak karena mendapat injeksi aloksan kemudian mengkonsumsi alginat dosis $1 \mathrm{~g} / \mathrm{kg}$ BB selama 15 hari.

Figure 7. Photograph of rat pancreatic beta-cell preparation

a. Preparation of normal rat pancreatic beta-cell (control).

b. Preparation of damage rat pancreatic beta-cell due to alloxan injection.

c. Preparation of damage rat pancreatic beta-cell due to alloxan injection followed by feeding alginate at the dose of $1 \mathrm{~g} / \mathrm{kg} \mathrm{BW}$ during 10 days

d. Preparation of damage rat pancreatic beta-cell due to alloxan injection followed by feeding alginate at the dose of $1 \mathrm{~g} / \mathrm{kg} \mathrm{BW}$ during 15 days 
penelitian menunjukkan bahwa glukosa dan aloksan bekerja pada lokasi yang sama atau berdampingan pada membran plasma sel beta. Aloksan bekerja pada membran sel dengan cara bereaksi dengan dua gugus sulfhidril $(-\mathrm{SH})$ yang berdampingan dengan jarak tertentu, sehingga konsumsi senyawa sulfhidril pada diet rendah protein dan cukup kalori merupakan upaya pemulihan yang dapat merusak kerja sitotoksik aloksan. Menurut Jensen (1948), berdasarkan analisis histologi pankreas setelah mendapatkan perlakuan aloksan menunjukkan terjadinya degranulasi dilanjutkan dengan degenerasi sel beta pankreas. Degenerasi sel beta tersebut mengakibatkan terjadinya penurunan produksi insulin. Menurut Dixit dan Kaung (1985), berkurangnya jumlah reseptor glukosa dan aloksan pada membran sel beta pankreas mengakibatkan defisiensi fungsional dari sel beta pankreas dalam merespon glukosa, yang akhirnya mengakibatkan menurunnya sekresi insulin. Terdapat beberapa kemungkinan penyebab menurunnya sekresi insulin, diantaranya adalah: (1) tidak cukup atau tidak sensitifnya sistem pengenalan glukosa (glukoreseptor, tempat regulator) pada permukaan sel beta; (2) menurunnya metabolisme glukosa dalam sel beta (tempat substrat); (3) terjadinya perubahan dalam komponen-komponen sel beta (mikrotube dan mikrofilamen) yang terlibat dalam sekresi insulin. Pemberian natrium alginat mengakibatkan terjadinya percepatan homeostasis glukosa, yang selanjutnya dapat membantu mempercepat proses perbaikan jaringan yang rusak, peningkatan jumlah dan sensitifitas reseptor glukosa, serta peningkatan aktivitas metabolisme dalam sel beta pankreas. Hal ini tampak dari hasil penelitian bahwa menurunnya kadar glukosa darah tikus dengan cepat setelah perlakuan maupun sebelum perlakuan dibandingkan dengan kontrol (Gb 2-4), serta hasil analisis histologis pankreas yang menunjukkan adanya indikasi terjadinya perbaikan sel beta pankreas secara bertahap yang telah mengalami kerusakan akibat pemberian senyawa aloksan (Gb. 7ad).

Dikemukakan oleh Orci et al. (1989) bahwa sel beta pankreas mensekresi insulin sebagai respon atas terjadinya peningkatan kadar glukosa darah. Asupan dan metabolisme glukosa oleh sel beta diperlukan untuk terjadinya sinyal. Menurut Niijima (1989), pankreas dihubungkan oleh cabang-cabang saraf saluran cerna (vagus). Adanya stimulasi listrik saluran cerna akan mengubah keluaran insulin dan glukagon dari pankreas. Stimulasi listrik terhadap syaraf saluran cerna yang berhubungan dengan pankreas menimbulkan peningkatan aktivitas total enzim glikogen sintetase. Hal ini menunjukkan bahwa eksitasi atau stimulasi saraf saluran cerna secara langsung akan memfasilitasi sekresi insulin dari sel beta pankreas dan menurunkan kadar glukosa darah dengan mempercepat glikogenesis atau sintesis glikogen di dalam liver. Konsumsi alginat oleh tikus penderita diabetes diduga menimbulkan peningkatan stimulasi reseptor glukosa yang terdapat pada usus halus atau saluran cerna, yang selanjutnya meningkatkan pelepasan insulin dari sel beta pankreas yang teraktifkan melalui saraf saluran cerna tersebut.

Orci et al. (1989) mengemukakan bahwa transporter glukosa jenis liver (GT liver-type) terdapat di dalam liver, usus dan ginjal, terekspresikan di dalam pulau pankreas. Di dalam usus halus, transporter jenis liver ini terdapat dalam membran plasma sel absorpsi. Hasil deteksi dengan metoda imunofluoresensi menunjukkan bahwa transporter glukosa jenis liver ini terdapat di dalam sel beta yang mengandung insulin tetapi tidak terdapat dalam sel endokrin lainnya (glukagon, somatostatin, dan polipeptida pankreas). Keadaan ini sesuai dengan sensitivitas sel beta pankreas khusus untuk merubah konsentrasi gkukosa ekstraseluler. Sensor glukosa di dalam sel beta pankreas dilengkapi dengan enzim pembatas laju metabolisme glukosa yang disebut glukokinase, sebagai pengatur perubahan konsentrasi glukosa intraseluler dan ekstraseluler. Laju glikolisis akan tergantung pada kecepatan relatif transpor glukosa dan fosforilasi glukosa. Perubahan metabolisme glukosa akan merefleksikan perubahan konsentrasi glukosa darah dan pada akhirnya memicu terjadinya sekresi insulin. Tikus yang menderita diabetes akibat mengalami kerusakan pankreas oleh zat sitotoksik aloksan, diduga setelah diberi larutan alginat secara teratur selanjutnya di samping mengalami pengendalian asupan glukosa ke dalam sistem pembuluh darah juga mengalami perbaikan-perbaikan pada sistem reseptor glukosa jenis liver yang terdapat pada sel-sel di usus halus yang turut serta memegang peranan penting pada tahap awal proses metabolisme glukosa.

Upaya pengendalian kadar glukosa darah 
dapat membantu memperlancar normalisasi proses metabolisme yang pada akhirnya akan membantu mempercepat proses perbaikan jaringan pankreas yang rusak (Dollet, 1985). Diabetes yang terjadi akibat adanya kerusakan pada jaringan sel beta pankreas oleh zat kimia aloksan diduga bukan akibat mutasi genetik atau hancurnya sel beta pankreas, tetapi karena jumlah reseptor glukosa dan/atau sénsitivitas reseptor glukosa pada sel beta makin menurun sehingga mengakibatkan terjadinya resistensi insulin. Permberian larutan alginat kepada tikus yang mengalami diabetes mengakibatkan terjadinya proses penurunan kadar glukosa darah tikus menuju ke keadaan normal yang berlangsung secara bertahap (Gb. 2-4). Hasil analisis histologi pankreas secara imunokimia menunjukkan terjadinya proses pemulihan /perbaikan jaringan pankreas yang sebelumnya telah mengalami kerusakan (Gb. 7a-d).

\section{KESIMPULAN}

Dari hasil penelitian dapat disimpulkan sebagai berikut:

1. Pemberian natrium alginat dosis $0,25 \mathrm{~g} / \mathrm{kg}$, $0,5 \mathrm{~g} / \mathrm{kg}$ dan $1,0 \mathrm{~g} / \mathrm{kg}$ bobot badan dapat menurunkan kadar glukosa darah tikus yang mengalami kondisi diabetes karena mengalami kerusakan pankreas akibat pemberian suntikan aloksan secara intravena dosis $125 \mathrm{mg} / \mathrm{kg}$ bobot badan. Penurunan kadar glukosa darah tikus secara berurutan, akibat pemberian natrium alginat dosis $1,0 \mathrm{~g} / \mathrm{kg}$ lebih besar dari pada dosis $0,5 \mathrm{~g} / \mathrm{kg}$, dan lebih besar dari pada dosis $0,25 \mathrm{~g} / \mathrm{kg}$ bobot badan. Dalam pada itu penurunan kadar glukosa darah tikus akibat pemberian injeksi insulin dosis 3,78 UI/kg bobot badan lebih besar dari pada pemberian natrium alginat dalam semua dosis.

2. Pemberian natrium alginat lebih banyak dapat membantu proses perbaikan sel beta pankreas yang mengalami kerusakan dibandingkan dengan pemberian injeksi insulin.

3. Perlu dilakukan penelitian lebih lanjut untuk mengetahui hubungan antara rasio manuronat/guluronat (M/G) yang terkandung dalam senyawa alginat dan variasi viskositas dengan kecepatan proses perbaikan sel beta pankreas yang mengalami kerusakan akibat pengaruh bahan kimia, serta mekanisme kerja senyawa alginat dalam membantu proses perbaikan sel beta pankreas yang telah mengalami kerusakan tersebut.

\section{DAFTAR PUSTAKA}

Anggadiredja, J. 1992. Pemanfaatan sumber daya hayati laut makro-algae dalam industri farmasi (makanan dan obat-obatan). Buletin DRN (27): 31-36.

Atmadja, W.S., 1988. Rumput Laut Sebagai Obat. Oseana, 17(1): 1-8.

Chapman, V.J. and Chapman, D.J. 1980. Seaweeds and Their Uses. Ed. 3. Chapman and Hall, London. p. 194-225.

Dixit, P.K. and Kaung, H.L.C. 1985. Rat pancreatic beta cells in protein deficiency: A study involving morphometric analysis and alloxan effect. J. Nutr. 115 (3): 377-380.

Dollet, M.J. 1985. Progressive adaptation of the endocrine pancreas during long-term protein deficiency in rats: Effects on blood glucose homeostasis and on pancreatic insulin, glucagon and somatostatin concentrations. J Nutr. 115 (12): 1581-1585.

Ganiswara, S.G. 1995. Farmakologi dan Terapi. Ed. 4. Fakultas Kedokteran Universitas Indonesia, Jakarta. $477 \mathrm{p}$

Ganong, W.F. 1992. Fisiologi Kedokteran. Ed. 14 Alih bahasa: P. Adrianto. EGC, Jakarta. 317 p.

Glicksman, M. 1983a. Food Hydrocoloids. Vol. I. CRC Press, Inc., Florida. p. 71-78.

Glicksman, M. 1983b. Food Hydrocoloids. Vol. II CRC Press, Inc., Florida. p. 115-188

Hern, E.P., Shroyer, L.A. and Varandani, P.T 1987. Insulin-degrading neutral cysteine proteinase activity of adipose tissue and liver of nondiabetic, streptozotocin-diabetic, and insulin-treated diabetic rats. Arch. Biochem. Biophys. 254 (1): 35-42.

Jensen, H. 1948. The internal secretion of the pancreas. In Pincus G. and Thiman, K.V. (eds.). The Hormones. Physiology, Chemistry and Applications. AP Presss, New York. p. 301-331.

Johnson \& Johnson, Co. 1995. Milpitas. Brosur Life Scan, CA 95035, USA. p. 1-4.

Katzung, B.G., 1989. Farmakologi Dasar dan Klinik. Ed. 3. Alih Bahasa: Binawati, H. K., EGC, Jakarta. 577 p.

KKI Phytomedica, 1993. Penapisan Farmakologi, Pengujian Fitokimia dan Pengujian Klinik. Yayasan Pengembangan Obat Bahan Alam, Phytomedica, Jakarta. p. 16-17

Laurence and Bacharah, 1964. Evaluation of Drug Activities Pharmacometrics. Academic Press, London. $161 \mathrm{p}$.

Niijima, A. 1989. Neural mechanisms in the control of blood glucose concentration. J. Nutr. 119: 833-840. 
Orci, L., Thorens, B., Ravazzola, M. and Lodish, H.F. 1989. Localization of the pancreatic beta cell glucose transporter to specific plasma membrane domains. Science 245: 295-297.

Reynoids, J.E.F. 1993. Martindale, The Extra Pharmacopeia. 13th Ed. The Pharmaceutical Press, London. 1217 p.

Suzuki, T., Nahai, K., Yoshie, Y., Shirai, T. dan Hirono, T. 1994. Effect of sodium alginates on mineral absorption and blood sugar of rats. $J$. Tokyo Univ. of Fish. 81(2): 93-99.

Tjokroprawito, A. 1999. Diabetes Melitus: Klasifikasi, Diagnosis dan Dasar-dasar Terapi. Gramedia, Jakarta. p. 1-10

Tulsiani, D.R.P. and Touster, O. 1981. Thymus involution and inhibition of spleen growth accompanies streptozotocin-induced diabetes in rats; Possible relationship of these changes to the elevated hydrolase levels in diabetic plasma. Arch. Biochem. Biophys. 208 (1): 59 68.

Wade, A. and Weller, P.J. 1994. Handbook of Pharmaceutical Excipents, 2nd Ed. The Pharmaceutical Press, London. p. 428-429.

Wikanta, T., 1996. Prospek Pengembangan dan pemanfaatan rumput laut (phaeophyceae) di Indonesia sebagai sumber senyawa alginat. $J$. Litbang Pertanian. p. 16-20.

Wikanta, T.D.S., Rejeki, and Rahayu, L.1998. The content and the physico-chemical characteristics of alginate extracted from three species of brown algae (S. cinereum, $\boldsymbol{H}$. triquetra, and $T$. conoides). Indon. Fish. Res. J. 4(1): 46-50.

Wikanta, T., Riyadi A. dan Rahayu, L. 2000. Pengaruh pemberian natrium alginat terhadap penurunan kadar glukosa darah kelinci dengan metoda toleransi glukosa oral. J. Octopus 4(1): $1-13$ 